Article

\title{
Petrology of Chromitites in the Higashi-Akaishi Ultrahigh-Pressure (UHP) Peridotite Complex, Japan: Toward Understanding of General Features of the UHP Chromitites
}

\author{
Makoto Miura ${ }^{1,2, *}$, Shoji Arai ${ }^{1}$, Tomoyuki Mizukami ${ }^{1}$, Vladimir R. Shmelev ${ }^{3}$ \\ and Satoko Ishimaru ${ }^{4}$ \\ 1 Department of Earth Sciences, Kanazawa University, Kakuma, Kanazawa 920-1192, Japan; \\ ultrasa@staff.kanazawa-u.ac.jp (S.A.); peridot@staff.kanazawa-u.ac.jp (T.M.) \\ 2 Gemological Institute of America (GIA) Tokyo Godo Kaisha, Tokyo 110-0016, Japan \\ 3 Zavaritsky Institute of Geology and Geochemistry, Ural Branch, Russian Academy of Sciences, \\ Yekaterinburg 620075, Russia; shmelev@igg.uran.ru \\ 4 Department of Earth and Environmental Sciences, Faculty of Advanced Science and Technology, \\ Kumamoto University, Kumamoto 860-8555, Japan; s_ishimaru@kumamoto-u.ac.jp \\ * Correspondence: makomiu1214@gmail.com; Tel.: +81-76-264-6513; Fax: +81-76-264-6545
}

Received: 9 October 2018; Accepted: 6 November 2018; Published: 11 November 2018

\begin{abstract}
Ultrahigh-pressure (UHP) chromitites containing UHP minerals such as coesite and diamond have been reported from some ophiolites in Tibet and the Polar Urals. Their nature, i.e., origin, P-T path and abundance, however, are still controversial and left unclear. Here we describe chromitites in the Higashi-akaishi (HA) ultramafic complex in the Cretaceous Sanbagawa metamorphic belt, Japan, which experienced UHP condition (up to $3.8 \mathrm{GPa}$ ) at the peak metamorphism via subduction, in order to understand the nature of UHP chromitites. The HA peridotites typically contain garnets and are associated with eclogites, and their associated chromitites are expected to have experienced the UHP metamorphism. The Higashi-akaishi (HA) chromitites show banded to massive structures and are concordant to foliation of the surrounding peridotite. Chromian spinels in the chromitite and surrounding peridotites were sometimes fractured by deformation, and contain various inclusions, i.e., blade- and needle-like diopside lamellae, and minute inclusions of pyroxenes, olivine, and pargasite. The peculiar UHP minerals, such as coesite and diamond, have not been found under the microscope and the Raman spectrometer. Spinels in the HA chromitites show high Cr\#s ( 0.7 to 0.85$)$, and low Ti contents $(<0.1 \mathrm{wt} \%)$, suggesting a genetic linkage to an arc magma. The HA chromitites share the basic petrographic and chemical features (i.e., diopside lamellae and arc-related spinel chemistry) with the UHP chromitites from Tibet and the Polar Urals. This suggests that some of the characteristics of the UHP chromitite can be obtained by compression, possibly via deep subduction, of low-P chromitite.
\end{abstract}

Keywords: chromitite; ultrahigh-pressure metamorphism; the Higashi-akaishi peridotite complex; diopside lamella; arc-related magmatism; subduction

\section{Introduction}

Podiform chromitites, which are mainly composed of chromian spinels, have been interpreted as an igneous cumulate precipitated from a spinel-oversaturated melt formed by melt/peridotite reaction at low-pressure (low-P) conditions [1,2]. Podiform chromitites from ophiolites, such as the Oman ophiolite, commonly show various lines of evidence for low-P origin, such as the frequent presence of 
pargasite inclusions in chromian spinel $[3,4]$. However, peculiar minerals indicating ultrahigh-pressure (UHP) and highly reduced conditions, such as diamond, moissanite, and alloys, have been found from chromitites and surrounding peridotites in several ophiolites such as Luobusa ophiolite of Tibet [5-9] and Ray-Iz ophiolite of the Polar Urals [7]. Origin of such UHP mineral-bearing chromitites (UHP chromitites) is still very controversial because their petrographic and petrologic features are unclear, although several models were proposed [5,7,10-12]. One of serious problems in constraining the origin of UHP chromitites is a lack of information on their P-T trajectory.

Chromitites from the Higashi-akaishi complex will give us a clue to clear this problem. The Higashi-akaishi (HA) peridotite body in the Sanbagawa metamorphic belt, Southwest Japan (Figure 1), has been interpreted to have originally formed at low-P conditions such as the uppermost mantle in a mantle wedge, and subsequently experienced UHP metamorphic condition up to $3.8 \mathrm{GPa}$, due to downgoing mantle flow induced by subduction [13-18]. The P-T trajectory has been established based on petrological and petrofabric studies of peridotites and related rocks, although UHP minerals have not been found [15]. Clear evidence for their high-P conditions is the existence of pyrope-rich garnet in peridotites [13]. We expect that the HA chromitites also have experienced the UHP metamorphism together with the associated peridotites. The advantage of the HA chromitite is that its P-T history has been independently determined [13-18]. The HA chromitites will, therefore, provide us with unrivaled information on the behavior of low-P chromitite upon compression via UHP metamorphism. We present here petrographic and petrological features of chromitites from the HA peridotite complex (Figure 1) in order to understand the nature of chromitites in the UHP metamorphic belt, or the UHP chromitites from ophiolites.

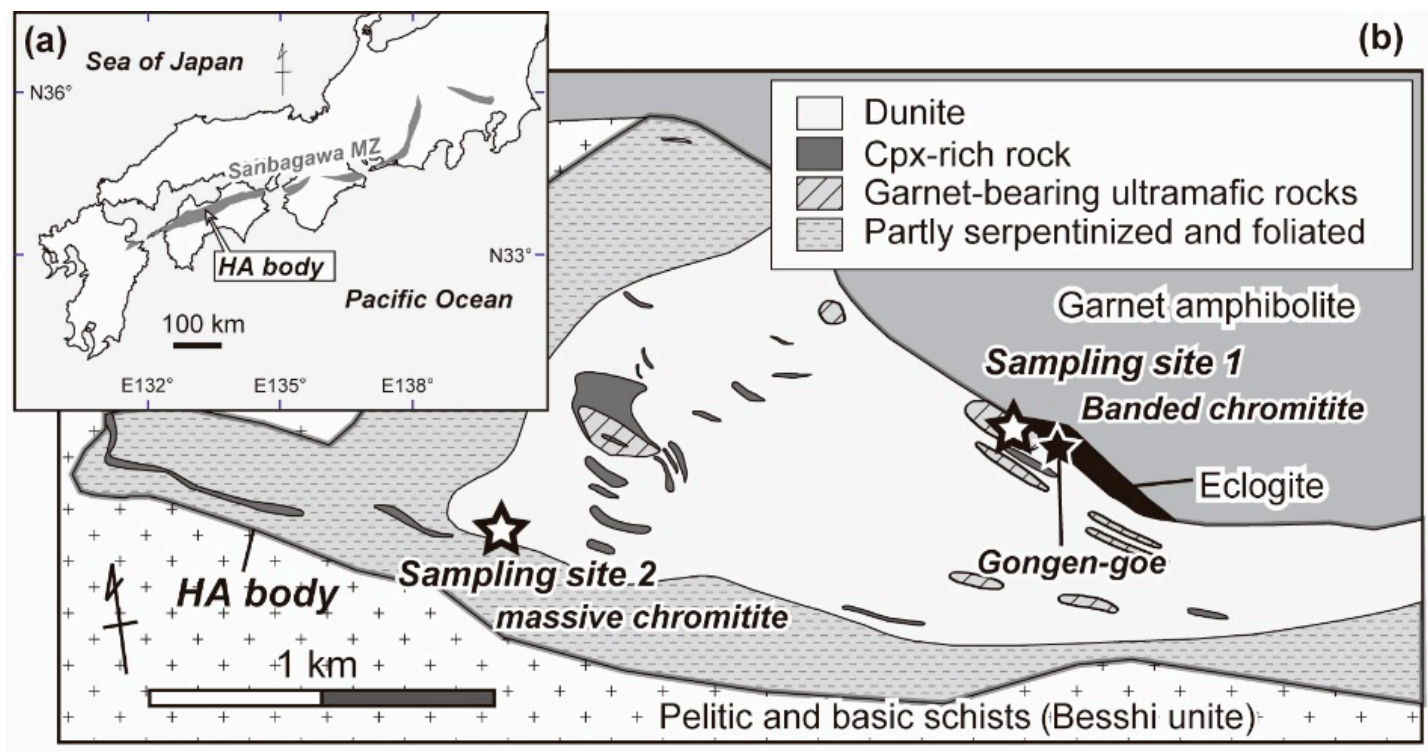

Figure 1. Locality and geological sketch maps of the Higashi-akaishi ultramafic complex located on the Sanbagawa high-P metamorphic zone. (a) Location of the Higashi-akaishi ultramafic complex. (b) General geological sketch of the Higashi-akaishi ultramafic complex and surrounding metamorphic rocks. Modified from Hattori et al. [17]. Open star, sampling localities.

\section{Geological Background}

The Sanbagawa belt, a Cretaceous regional metamorphic belt, extends over $800 \mathrm{~km}$ along southwest Japan arc (Figure 1a), and is mainly composed of pelitic and basic schists with small numbers of metagabbro and ultramafic bodies $[14,19,20]$. The Higashi-akaishi (HA) ultramafic complex is one of the largest ultramafic complexes in the Sanbagawa metamorphic belt (Figure 1). Ultramafic rocks from the HA complex are dominated by dunites, which contain layers of clinopyroxenite and websterite with small amounts of chromitite (Figure 1). A unit of eclogite exists along the contact (the Gongen-goe 
area) between the HA peridotite and surrounding garnet amphibolite (Figure 1). Ultramafic rocks have experienced eclogite facies metamorphism because of the presence of pyrope-rich garnet $[14,19]$. Chromitites occur as sparse concordant to subconcordant lenses and layers within dunites (Figure 2). The HA chromitites vary from banded to massive types with an increase in the degree of deformation and chromite modal amount [21] (Figure 2b,c). Thick chromitite lenses have been almost mined out, but a few small/thin lenses still remain in dunite-dominant portion of the complex [22]. The HA peridotites and included chromitite lenses are strongly deformed and folded near the garnet amphibolite body of the Gongen-goe area (Figure 2b). Chromitite samples from the central part of the HA complex are far less deformed than the banded chromitites in the Gongen-goe area (Figure 2c).
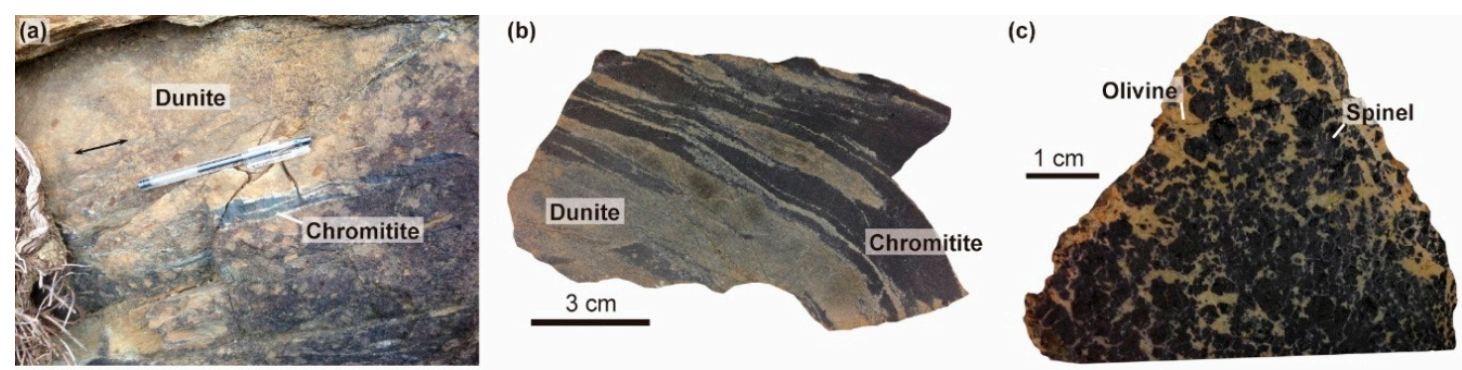

Figure 2. Chromitites from the Higashi-akaishi ultramafic complex. (a) Banded chromitite pods in dunite closed to the contact with eclogite-facies rocks (Figure 1). Chromitite is concordant to the foliation of the surrounding dunite (black arrow). (b) A folded banded chromitite in a boulder from scree near the Gongen-goe. Note the strongly deformed nature. (c) A massive chromitite sample (boulder) from sampling site 2. Yellowish part (silicate matrix) is composed of olivine.

\section{Materials and Methods}

Chromitite samples were collected from outcrops and boulders at two sites in the Higashi-akaishi ultramafic complex (Figure 1). Polished thin sections of chromitites were examined with microscope for petrographic observation (Figure 3), and tested with Raman spectroscopy and a microprobe at Kanazawa University, Japan.

Laser-Raman spectroscopy (LabRAM HR800, HORIBA Jobin Yvon) with a $532 \mathrm{~nm}$ Nd:YAG laser (J100GS-16, Showa Optronics Co., Ltd.) of Department of Earth Sciences at Kanazawa University was used to identify minute silicate lamellae and inclusions within chromite. The Nd:YAG laser has an irradiation power at $1.6 \mathrm{~mW}$ with a spectral resolution of about \pm 2.5 to $\pm 3.5 \mathrm{~cm}^{-1}$. For tiny inclusions and exsolutions in host chromites, and the gained Raman spectra were processed to remove the signal of host chromite using LabSpec software (Version 5) as shown in Figure 4.

Minerals were analyzed by a wave-length dispersive electron microprobe (JXA8800R, JEOL) at Kanazawa University. Analytical conditions were $20 \mathrm{kV}$ accelerating voltage, $20 \mathrm{nA}$ probe current, and 3 or $0 \mu \mathrm{m}$ probe diameter for quantitative spot analysis (Figure 5, Table 1). A $20 \mathrm{kV}$ accelerating voltage and a $100 \mathrm{nA}$ probe current with a beam diameter of $<1 \mu \mathrm{m}$ were used for elemental distribution maps (Figure 6). Natural and synthetic minerals were used as standards, and the ZAF matrix correction algorithm was used during data reduction. Ferrous and ferric iron contents of chromian spinel were calculated assuming spinel stoichiometry, while all iron was assumed to be $\mathrm{Fe}^{2+}$ in silicates. $\mathrm{Mg} \#$ is $\mathrm{Mg} /\left(\mathrm{Mg}+\mathrm{Fe}^{2+}\right)$ atomic ratio, and $\mathrm{Cr} \#$ is $\mathrm{Cr} /(\mathrm{Cr}+\mathrm{Al})$ atomic ratio. 


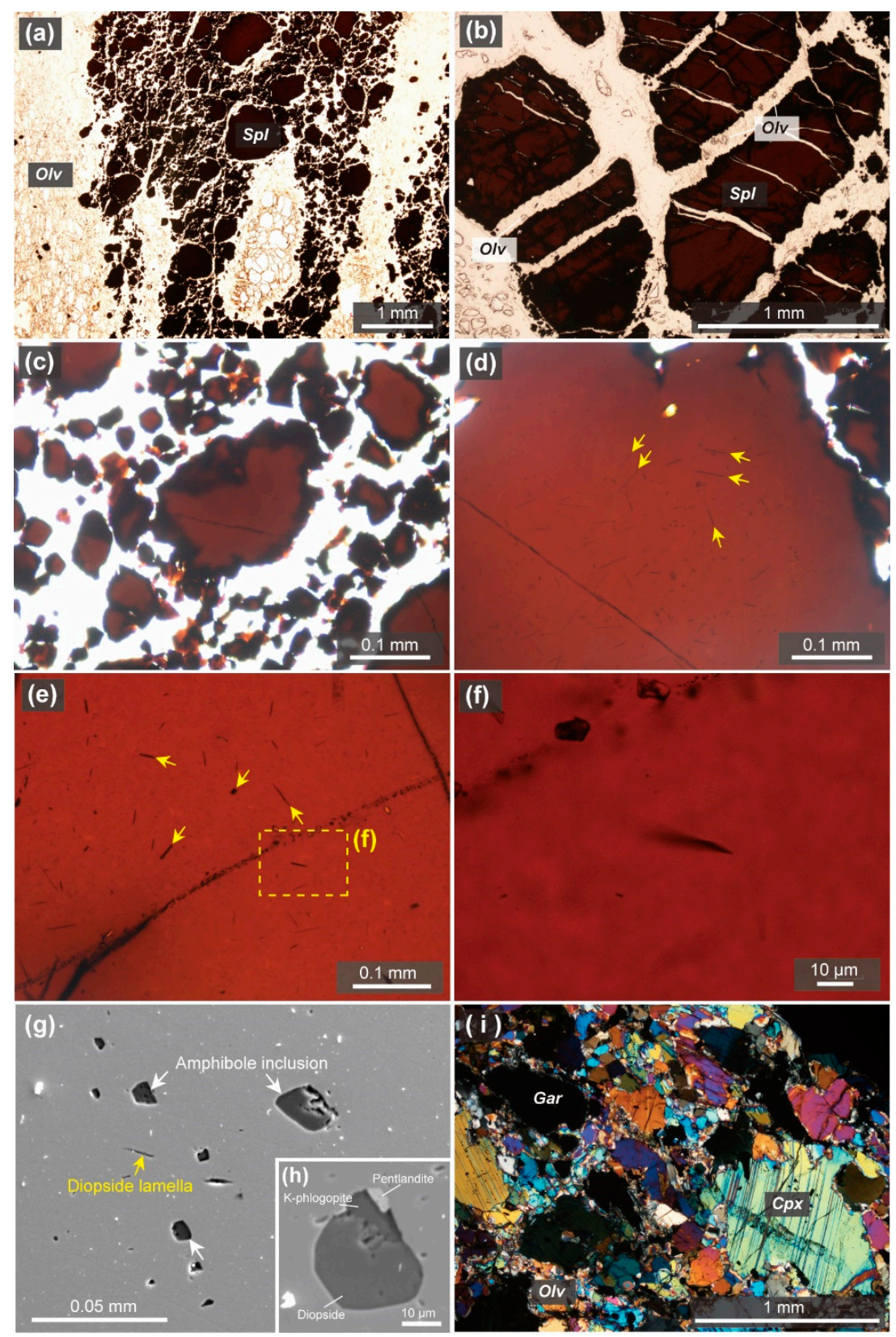

Figure 3. Photomicrographs of chromitites and surrounding garnet-bearing wehrlite from the Higashi-akaishi ultramafic complex. Plane-polarized light $(\mathbf{a}-\mathbf{f})$, backscattered electron $(\mathbf{g}-\mathbf{h})$ and crossed-polarized light (i) images. (a) Banded chromitite (HC123) from the Gongen-goe (sampling site in Figure 1b). Note that spinels are strongly deformed. (b) Massive chromitite (HA-1) from western part of the Higashi-akaishi ultramafic complex (sampling site 2 in Figure 1b). Note the olivine-filled fractures in spinel. (c) Close-up image of a fine-grained part in banded chromitite (HC-123). (d) Close-up image of a coarse spinel grain in banded chromitite (HC-123). Note that the only core part contains numerous needle- and blade-like silicate lamellae. (e) Spinel of the massive chromitite (HA-1) containing silicate lamellae (yellow arrow). Several silicate lamellae show parallelism. (f) Close-up image of a blade-like silicate lamella. (g) Back-scattered electron image of primary silicate mineral inclusions (pyroxenes and amphibole) (white arrows) and silicate exsolution. (h) Back-scattered electron image of a primary inclusion composed of diopside + K-phlogopite + pentlandite in spinel. (i) Surrounding garnet-bearing wehrlite from the Gongen-goe mountain path. 


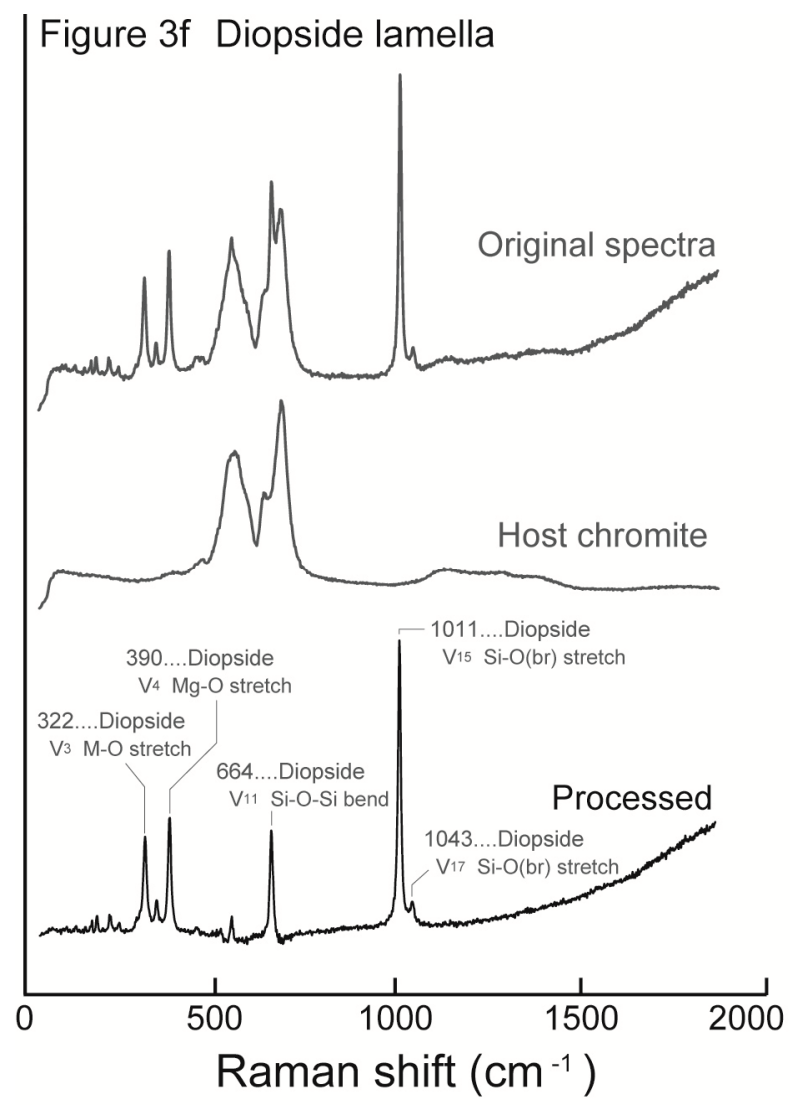

Figure 4. A typical Raman spectrum of diopside exsolution lamella in chromite from massive chromitite. Effect from host chromite was removed from the original spectrum by using LabRam Version 5 software (HORIBA) at Kanazawa University.

Table 1. Selected microprobe analyses of spinel and associated silicate minerals from the HA chromitites.

\begin{tabular}{|c|c|c|c|c|c|c|c|c|c|c|}
\hline $\begin{array}{c}\text { Texture } \\
\text { Mineral } \\
\text { Sample No. }\end{array}$ & $\begin{array}{l}\text { Chr. } \\
\text { 01a-1 }\end{array}$ & $\begin{array}{c}\text { Olv. } \\
01 a-6\end{array}$ & $\begin{array}{c}\text { Massive } \\
\text { Chl. } \\
02-06\end{array}$ & $\begin{array}{c}\text { Dio. In } \\
02-10\end{array}$ & $\begin{array}{c}\text { Chl. In } \\
02-05\end{array}$ & $\begin{array}{l}\text { Chr. } \\
\text { 123-15 }\end{array}$ & $\begin{array}{l}\text { Olv. } \\
123-19\end{array}$ & $\begin{array}{c}\text { Banded } \\
\text { Dio. In } \\
123-23\end{array}$ & $\begin{array}{l}\text { Par. In } \\
123-14\end{array}$ & $\begin{array}{c}\text { Phl. In } \\
123-22\end{array}$ \\
\hline $\mathrm{SiO}_{2}$ & - & 42.41 & 34.88 & 55.70 & 34.11 & - & 42.96 & 56.11 & 45.88 & 41.90 \\
\hline $\mathrm{TiO}_{2}$ & 0.12 & - & - & 0.02 & - & 0.24 & - & 0.06 & 0.22 & 0.08 \\
\hline $\mathrm{Al}_{2} \mathrm{O}_{3}$ & 9.08 & - & 9.33 & 0.48 & 12.99 & 12.10 & - & 0.56 & 11.75 & 14.38 \\
\hline $\mathrm{Cr}_{2} \mathrm{O}_{3}$ & 59.95 & - & 6.62 & 1.63 & 3.64 & 57.04 & - & 0.94 & 2.93 & 1.38 \\
\hline $\mathrm{FeO}^{*}$ & 22.28 & 5.42 & 2.17 & 1.24 & 1.90 & 20.55 & 4.55 & 1.32 & 2.37 & 1.33 \\
\hline $\mathrm{MnO}$ & 0.41 & 0.08 & 0.03 & 0.05 & 0.02 & 0.38 & 0.06 & 0.05 & 0.03 & - \\
\hline $\mathrm{MgO}$ & 9.23 & 54.02 & 33.42 & 17.99 & 34.48 & 11.75 & 54.17 & 18.10 & 19.95 & 27.56 \\
\hline $\mathrm{CaO}$ & - & - & - & 24.39 & - & - & 0.01 & 24.29 & 12.13 & 0.10 \\
\hline $\mathrm{Na}_{2} \mathrm{O}$ & - & - & - & 0.33 & - & - & - & 0.35 & 3.25 & 0.45 \\
\hline $\mathrm{K}_{2} \mathrm{O}$ & - & - & - & 0.01 & - & - & - & 0.01 & 0.92 & 8.89 \\
\hline $\mathrm{NiO}$ & 0.03 & 0.37 & 0.21 & 0.03 & 0.22 & 0.06 & 0.35 & 0.04 & 0.09 & 0.20 \\
\hline Total & 101.09 & 102.3 & 86.68 & 101.87 & 87.38 & 102.12 & 102.10 & 101.83 & 99.51 & 96.25 \\
\hline $\mathrm{Mg} \#$ & 0.455 & 0.947 & 0.965 & 0.963 & 0.970 & 0.555 & 0.955 & 0.961 & 0.938 & 0.974 \\
\hline Cr\# & 0.816 & & & & & 0.760 & & & & \\
\hline $\mathrm{Y}_{\mathrm{Cr}}$ & 0.787 & & & & & 0.721 & & & & \\
\hline $\mathrm{Y}_{\mathrm{Al}}$ & 0.178 & & & & & 0.228 & & & & \\
\hline $\mathrm{Y}_{\mathrm{Fe} 3+}$ & 0.035 & & & & & 0.051 & & & & \\
\hline
\end{tabular}

Abbreviations are as follows: Chr., chromite; Olv., olivine; Chl., chlorite; Dio. In, diopside inclusion in chromite; Chl. In, chlorite inclusion; Par. In, pargasite inclusion; Phl. In, phlogopite inclusion. FeO*, total iron as FeO; Mg\#, $\mathrm{Mg} /\left(\mathrm{Mg}+\mathrm{Fe}^{2+}\right)$ atomic ratio; $\mathrm{Cr} \#, \mathrm{Cr} /(\mathrm{Al}+\mathrm{Cr})$ atomic ratio; $\mathrm{Y}_{\mathrm{Cr}}, \mathrm{Cr} /\left(\mathrm{Al}+\mathrm{Cr}+\mathrm{Fe}^{3+}\right)$ atomic ratio; $\mathrm{Y}_{\mathrm{Al}}, \mathrm{Al} /(\mathrm{Al}+\mathrm{Cr}$ $\left.+\mathrm{Fe}^{3+}\right)$ atomic ratio; $\mathrm{Y}_{\mathrm{Fe} 3+}, \mathrm{Fe}^{3+} /\left(\mathrm{Al}+\mathrm{Cr}+\mathrm{Fe}^{3+}\right)$ atomic ratio. Horizontal line (-) means below the detection limits. 


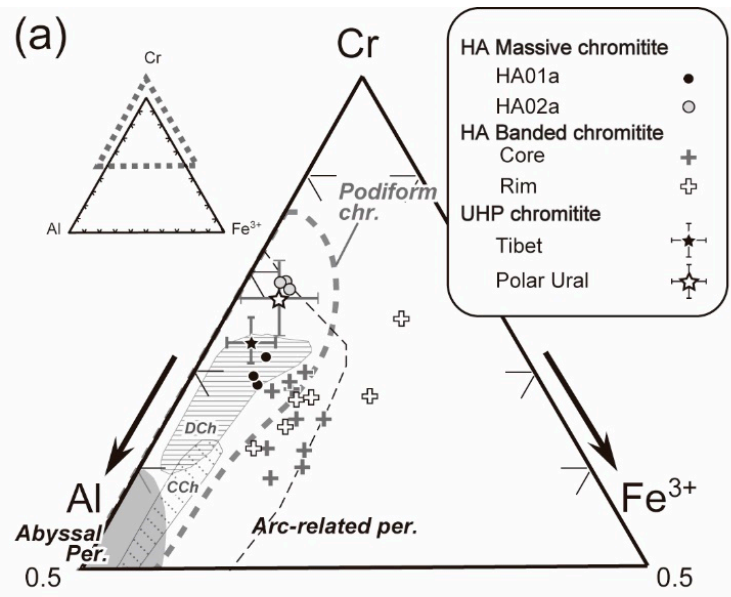

(b)
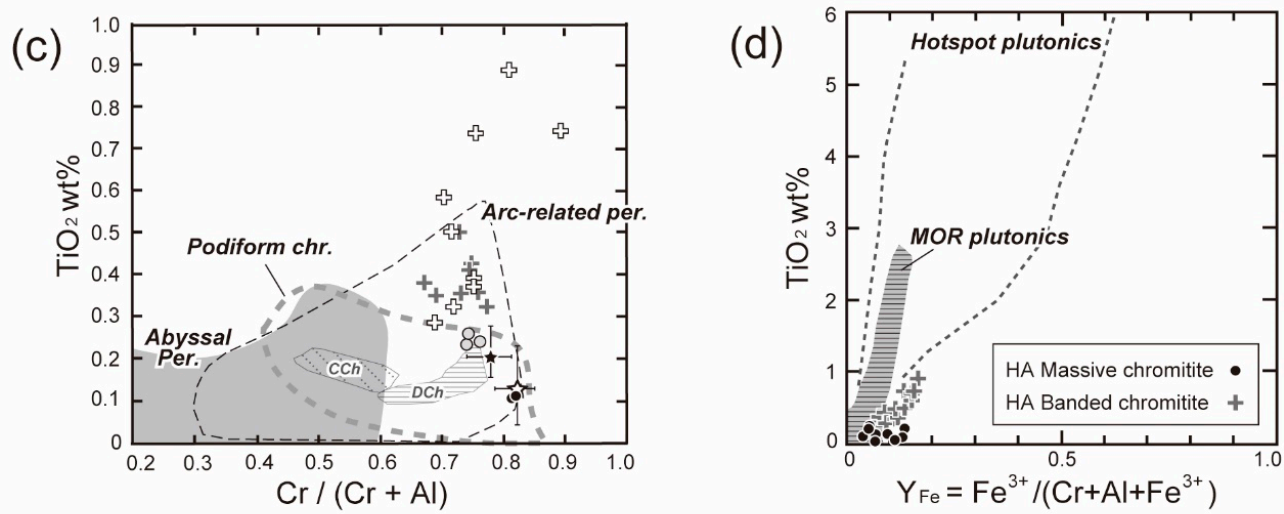

Figure 5. Chemical characteristics of chromian spinel from the Higashi akaishi chromitites and ultrahigh-pressure chromitites from Tibet and the Polar Urals. (a) Trivalent cation $\left(\mathrm{Cr}, \mathrm{Al}\right.$, and $\mathrm{Fe}^{3+}$ ) diagrams. (b) Relationships between $\mathrm{Mg} \#\left(\mathrm{Mg} /\left(\mathrm{Mg}+\mathrm{Fe}^{2+}\right)\right.$ atomic ratio $)$ and $\mathrm{Cr} \#(\mathrm{Cr} /(\mathrm{Cr}+\mathrm{Al})$ atomic ratio). (c) Relationships between $\mathrm{Cr} \#$ and $\mathrm{Ti}$ content in spinel. Note that rim of spinel in banded chromitite is rich in Ti. (d) Relationships between $\mathrm{TiO}_{2}$ content and $\mathrm{Fe}^{3+} /\left(\mathrm{Cr}+\mathrm{Al}+\mathrm{Fe}^{3+}\right)$ atomic ratio for the HA chromitites. Fields for MOR plutonics and hot-spot plutonics are quoted from Arai et al. [23]. Compositional fields of concordant (CCh) and discordant (DCh) chromitites from Northern Oman ophiolite are plotted in $(\mathbf{a}-\mathbf{c})$ for comparison [24]. Note that spinels from the HA chromitites show a sub-arc trend.



Figure 6. Backscattered electron image and elemental distribution map of a diopside lamellae-bearing spinel grain (center) in a banded chromitite sample (HC123 from sampling site 1 in Figure 1). Rim of the spinel grain shows high total Fe and slightly low Al contents relative to the core of spinel. (a) BSE image. (b) Fe distribution map. (c) Al distribution map. Al-rich mineral surrounding the spinel grain is chlorite. 
Three chromitite samples were analyzed for all Platinum-group elements (PGEs; Os, Ir, Ru, Rh, Pt and Pd) (Figure 2c; Table 2). The whole-rock PGE contents in chromitite samples were determined by using ICP-MS after Ni-sulfide fire assay collection at the Genalysis Perth Laboratory Services, Australia. The detection limits are $1 \mathrm{ppb}$ for all PGEs.

Table 2. Whole-rock analyses of bulk-rock platinum group element compositions (ppb) in the HA chromitites.

\begin{tabular}{cccccccccc}
\hline Sample & Os & $\mathbf{I r}$ & $\mathbf{R u}$ & $\mathbf{R h}$ & $\mathbf{P t}$ & $\mathbf{P d}$ & Total (ppb) & $\mathbf{P d} / \mathbf{I r}$ & $\mathbf{R u} / \mathbf{P t}$ \\
\hline HA-1 & 28 & 29 & 100 & 11 & 3 & 3 & 174 & 0.10 & 33.33 \\
HA-2 & 9 & 17 & 67 & 8 & 8 & 5 & 114 & 0.29 & 8.38 \\
HA-3 & 23 & 45 & 115 & 19 & 48 & 104 & 354 & 2.31 & 2.40 \\
\hline
\end{tabular}

\section{Results}

\subsection{Petrography of the Higashi-Akaishi Chromitites}

Chromitites comprise euhedral to subhedral chromian spinel, olivine, serpentine, chlorite with minor amounts of amphibole (Figure 3). Some chromitite samples show a severe hydrothermal alteration, and typically contain kämmereite, chlorite, serpentine and a small amount of phlogopite, uvarovite and ehimeite, which is a Cr-dominant member of Ca amphibole [25]. Chromian spinels in the chromitites are reddish to dark brown in thin section, indicating their $\mathrm{Cr}$-rich character (Figure 3). Spinels in the banded chromitites are highly deformed and fractured (Figure 3a). Some of spinels in the chromitites and associated dunite have thin cracks filled by olivine, suggesting brittle and ductile behaviors of spinel and olivine, respectively, at the high- $T$ deformation stage (Figure $3 b$ ). Grain boundaries of olivines in dunite surrounding the banded chromitites show a triple junction, suggesting its textural equilibrium via recrystallization. The core of coarse spinel grains from the massive and banded chromitites typically contains numerous needle- and rod-shaped silicate lamellae, showing parallelism (Figure 3d-f). The silicate lamellae are especially prominent in the banded chromitites. The amount and frequency of lamellae decreases towards the marginal part of the grain (Figure 3d). This is basically similar to the distribution of clinopyroxene exsolution lamellae in orthopyroxene grains commonly observed in peridotites, which experienced cooling and decompression (Figure 7). Surrounding fine spinel grains do not contain silicate lamellae (Figure 3c). Minute (several tens microns) orbicular inclusions composed of clinopyroxene, amphibole, olivine, chlorite, and K-phlogopite are found from some of spinel grains in the HA chromitites (Figure 3g). They usually show sparse non-linear distributions in thin section indicating a primary origin. Solid-phase secondary inclusions are mostly composed of chlorite and antigorite. Platinum-group element minerals (PGM) have not been found from the HA chromitites.

Dunites comprise mosaic olivine, euhedral to subhedral spinel, antigorite and a small amount of clinopyroxene. Some of chromian spinels show strong deformation textures such as fracturing. The peridotites adjacent to the banded chromitite bodies typically contain clinopyroxene, garnet, and subhedral to anhedral spinel (Figure 3i). 

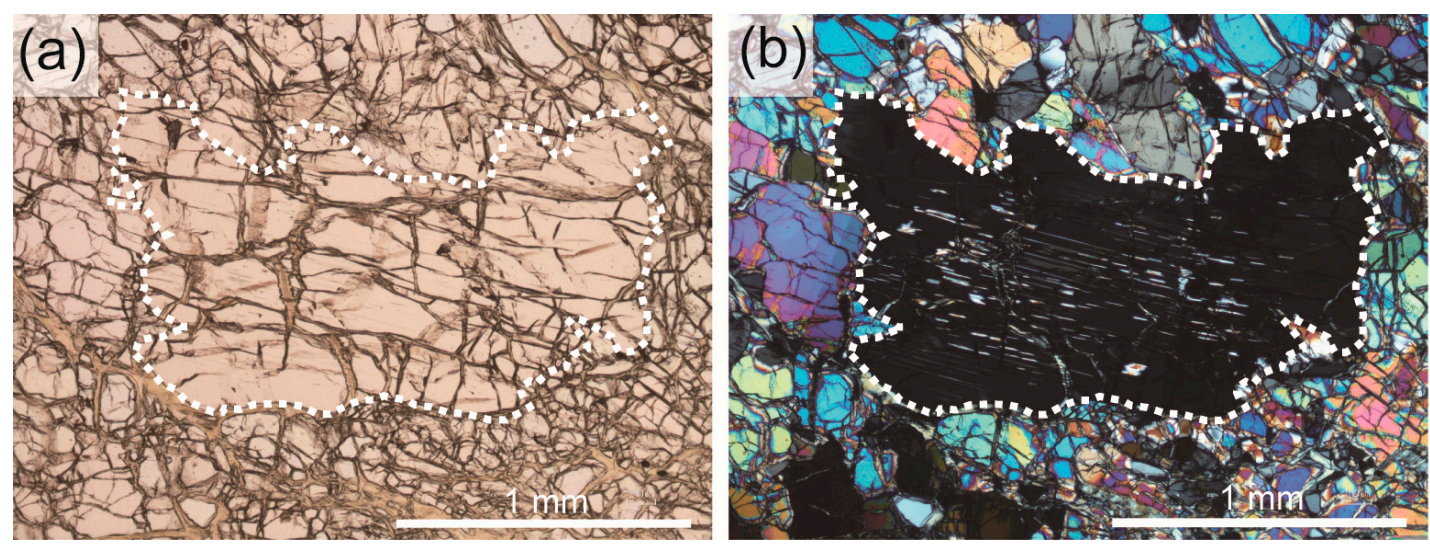

Figure 7. Photomicrographs showing a typical exsolution texture in orthopyroxene porphyroclast in mantle harzburgite (Wadi Rajmi area, northern Oman ophiolite) due to subsolidus cooling. (a) Plane-polarized image; (b) Crossed-polarized image. Note that clinopyroxene lamellae decrease in abundance towards the marginal part in the orthopyroxene grain (white dotted line). Compare with Figure 3d.

\subsection{Raman Spectroscopic Features of Inclusions}

Raman spectroscopy revealed that the exsolution lamellae within chromites from massive and banded HA chromitites are mainly diopside (Figure 4). A typical exsolution lamella (Figure 4) shows Raman spectroscopic features of diopside [25]. The minute orbicular silicate inclusions (Figure 3g) in spinels from chromitites are composed of clinopyroxene, amphibole, olivine, chlorite, and phlogopite as described above. Microprobe analyses suggest that the amphibole and mica phases in the orbicular inclusions are pargasite and K-phlogopite, respectively, as described below (Table 1).

\subsection{Mineral Chemistry}

Core of chromian spinels from the HA chromitites shows high Cr\#s, 0.65 to 0.82 , and low $\mathrm{TiO}_{2}$ contents, 0.1 to 0.5 (Figure 5). Chromian spinels are slightly higher in $\mathrm{Cr} \#$ in the massive HA chromitites than in the banded HA chromitites (Figure 5a). The Cr\# of spinel ranges from 0.72 to 0.82 for the massive chromitite pods, and 0.65 to 0.78 in the banded chromitite pods (Figure 5b). Spinels show zonation in terms of $\mathrm{Fe}^{3+}, \mathrm{Al}$ and $\mathrm{Ti}$ [26] in the banded chromitites (Figures 5 and 6), where the rim of spinel grains contrastingly shows a relatively high $\mathrm{Fe}^{3+}$ content, suggesting chemical modification of spinel in low-T alteration [27] (Figure 5a,c). Core of the coarse spinel grains containing diopside lamellae (Figure 3d) shows a low Fe (total) content and a slightly high Al content as compared with the rim (Figure 6). Surrounding fine spinel grains free of diopside lamellae (Figure 3c) show higher Fe (total) and lower $\mathrm{Al}$ contents.

Olivines show slightly higher Fo (=100 Mg\#) values, 94 to 96 , in the massive HA chromitites than in the banded ones ( $\mathrm{Fo}_{92-95}$ ) (Figure 8), described by Hattori et al. [17]. The $\mathrm{NiO}$ content of olivines varies from 0.30 to $0.42 \mathrm{wt} \%$ in the HA chromitites, being clearly lower than in ordinary podiform chromitites from ophiolites and almost equivalent to the value in residual mantle peridotites (Figure 8). 


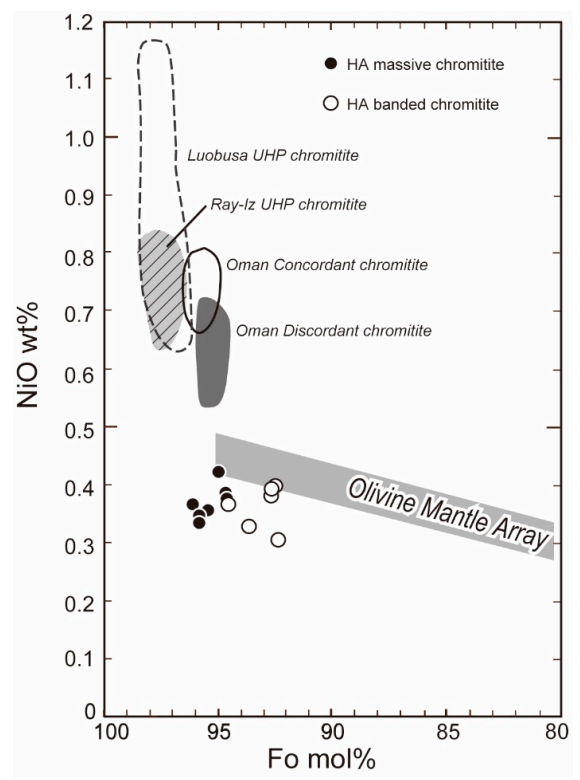

Figure 8. Relationships between Fo mol \% and $\mathrm{NiO}$ content of olivines from the Higashi akaishi chromitites. Chemical ranges for chromitites from Oman, Tibet, and the Polar Urals, are from Arai and Miura [28]. Compositional range of Olivine Mantle Array is from Takahashi et al. [29]. Note that olivines in the HA chromitites show lower Ni contents than in podiform chromitites from Oman ophiolite. On the other hand, olivines in UHP chromitites from Tibet and the Polar Urals show extraordinary higher $\mathrm{Ni}$ and $\mathrm{Mg}$ contents than in the HA chromitites.

\subsection{Platinum-Group Element Chemistry}

Massive chromitite samples (HA-1, 2, and 3 in Table 2) are high in total PGE, 174, 114 and 354 ppb, respectively (Figure 9a; Table 2). Two chromitite samples (HA-1 and 2) are distinctly enriched in Ir subgroup PGE (IPGE: Os, Ir, Ru) in preference to Pd subgroup PGE (PPGE: Rh, Pt, Pd) and show low ratios of Pd/Ir (around 0.1 to 0.3) (Figure 9b; Table 2). They show negative slopes from Ru to $\mathrm{Pt}$ in their chondrite-normalized PGE patterns (Figure 9b) as in typical ophiolitic chromitites [30]. Their enrichment in Ir and $\mathrm{Ru}$ is similar to that of the Oman arc-related discordant chromitites [30]. One chromitite sample (HA-3) showing the features of some high-degree modification at low T, e.g., $\mathrm{Fe}^{3+}$ enrichment and formation of chlorite is clearly enriched in PPGE (Figure 9b).
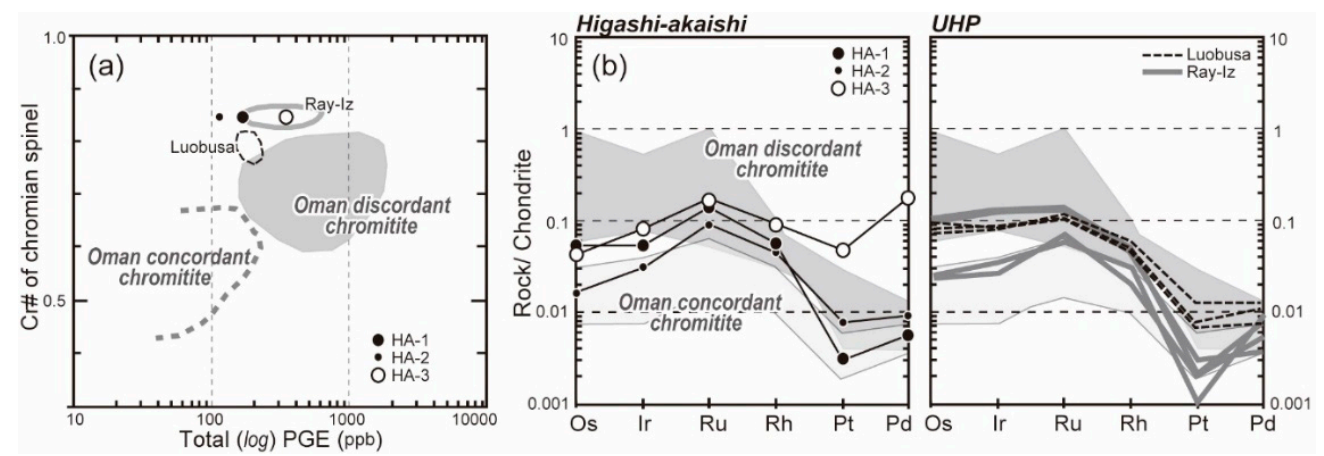

Figure 9. Bulk-rock PGE characteristics of massive chromiitte samples from the Higashi akaishi chromitite samples. Fields of chromitites from Oman were quoted from Ahmed and Arai [30] and Miura and Arai (unpublished data). Compositional fields of UHP chromitites from Tibet and the Polar Urals are shown for comparison [24]. (a) Relationships between the total bulk PGE content in chromitites and Cr\# of their spinels. (b) PGE patterns of the Higashi-akaishi massive chromitites. One sample enriched in $\mathrm{Pt}$ and $\mathrm{Pd}$ is strongly hydrated at low-T conditions. 


\section{Discussion}

\subsection{P-T History of the Higashi-Akaishi Chromitite}

The HA complex shows a counterclockwise P-T trajectory, which was caused by subduction and exhumation, are divided into four deformation stages, $\mathrm{D}_{1}, \mathrm{D}_{2}, \mathrm{D}_{3}$, and $\mathrm{D}_{4}$ [31] in terms of microstructure of minerals. Petrological and geochemical studies suggest that the HA peridotite complex originated as plutonics in an uppermost part of the mantle wedge [14,17,31,32]. After the igneous formation, the proto-HA peridotite complex subsided via the subduction channel by an active mantle flow $\left(D_{1}\right.$ and $D_{2}$ stage) $[14,15]$. The coexistence of forsterite-rich olivine and pyrope in ultramafics indicates that the HA body underwent high-P conditions (>1.8 GPa) $[19,33]$. Enami et al. [14] examined the olivine-pyroxenes-garnet assemblage in garnet clinopyroxenite, websterite, and wehrlite from the Gongen-goe area (Figure 1), and obtained a series of P-T conditions of the prograde metamorphism conducted by the subduction. They used $\mathrm{Al}$ solubility in orthopyroxene in equilibrium with garnet in the HA garnet peridotite, and delineated a P-T trajectory with a high $\mathrm{P} / \mathrm{T}$ gradient $\left(>3.1 \mathrm{GPa} / 100{ }^{\circ} \mathrm{C}\right)$ from $1.5-2.4 \mathrm{GPa}$ at $700-800{ }^{\circ} \mathrm{C}$ to $2.9-3.8 \mathrm{GPa}$ at $700-810{ }^{\circ} \mathrm{C}$ (Figure 10). Such P-T conditions are consistent with features of crystallographic preferred orientations (CPO) of olivines [16]. Mizukami et al. [16] reported B-type CPO in olivines [34] from HA peridotites. This strongly suggests that the olivines were deformed at hydrous and high-stress conditions such as in the supra-subduction zone mantle during the prograde metamorphism $\left(\mathrm{D}_{2}\right.$ stage). The coexistence of olivine and antigorite in strongly foliated peridotites in the marginal part of the HA complex provides us with a possible uplift path $\left(\mathrm{D}_{3}\right)$ from the peak of prograde metamorphism, i.e., $3.8 \mathrm{GPa} / 700{ }^{\circ} \mathrm{C}$ to around $1.0 \mathrm{GPa} / 500{ }^{\circ} \mathrm{C}$ [31] (Figure 10). After the $\mathrm{D}_{3}$ stage, the HA complex followed an exhumation path $\left(\mathrm{D}_{4}\right)$ similar to the clockwise P-T trajectory of the surrounding Besshi unit, which mainly consists of pelitic and basic schists, and that path $\left(\mathrm{D}_{4}\right)$ is related to the regional exhumation of the Sanbagawa belt (Figure 1). Then, retrograde amphiboles in garnet peridotite were probably formed at around 1.0 GPa and $600-700{ }^{\circ} \mathrm{C}[14,31]$ (Figure 9). In short, the HA complex was originally formed at an uppermost part of a mantle wedge and subsequently experienced UHP conditions, up to $3.8 \mathrm{GPa}$, before exhumation to the surface: it is of recycling origin along the boundary of the mantle wedge (Figure 10).

The HA chromitites are coherent to the surrounding peridotites (Figure 2) and they altogether share the same P-T trajectory (Figure 10). The chemical characteristics of the HA chromitites are consistent with this recycling model. Spinels from the HA peridotites show high Cr\#s $(>0.6)$, suggesting that the arc-related magma formed by high degree of partial melting was involved in formation of the HA ultramafic complex [17,32]. The spinel and PGE chemistries of the HA chromitites are also consistent with this interpretation (Figures 5 and 9). The core of chromian spinels in the HA chromitites shows high Cr\#s (0.65 to 0.85 ) and low $\mathrm{TiO}_{2}$ contents ( $<0.5 \mathrm{wt} \%$ ) (Figure 5$)$, suggesting the arc-magma parentage [31]. The $\mathrm{HA}$ chromitite spinels show the depletion in $\mathrm{TiO}_{2}$ content at a given $\mathrm{Fe}^{3+} /\left(\mathrm{Cr}+\mathrm{Al}+\mathrm{Fe}^{3+}\right)$ atomic ratio of spinels (Figure $5 \mathrm{c}$ ), which is characteristic of plutonics of a sub-arc origin [23] (Figure 5d). The enrichment of IPGE, such as Ir and Ru, and the negative slope from $\mathrm{Ru}$ to Pd in the PGE patterns (Figure 9b) suggest that the magma responsible for the formation of the HA chromitites had a highly depleted character [30]. The HA chromitites are also similar in the spinel chemistry and PGE chemistry to arc-related discordant chromitites from northern Oman ophiolite (Figures 5 and 9). The Fo and $\mathrm{NiO}$ contents of olivine in chromitites have been enhanced through subsolidus re-equilibration with chromian spinel [35,36]. Original igneous olivines in the HA chromitites were lower in Fo and Ni contents than the current values. The HA chromitite olivines (Figure 8) indicate an evolved nature of the involved magma, a relationship which possibly means a strong action of olivine fractionation during the HA chromitite formation. 


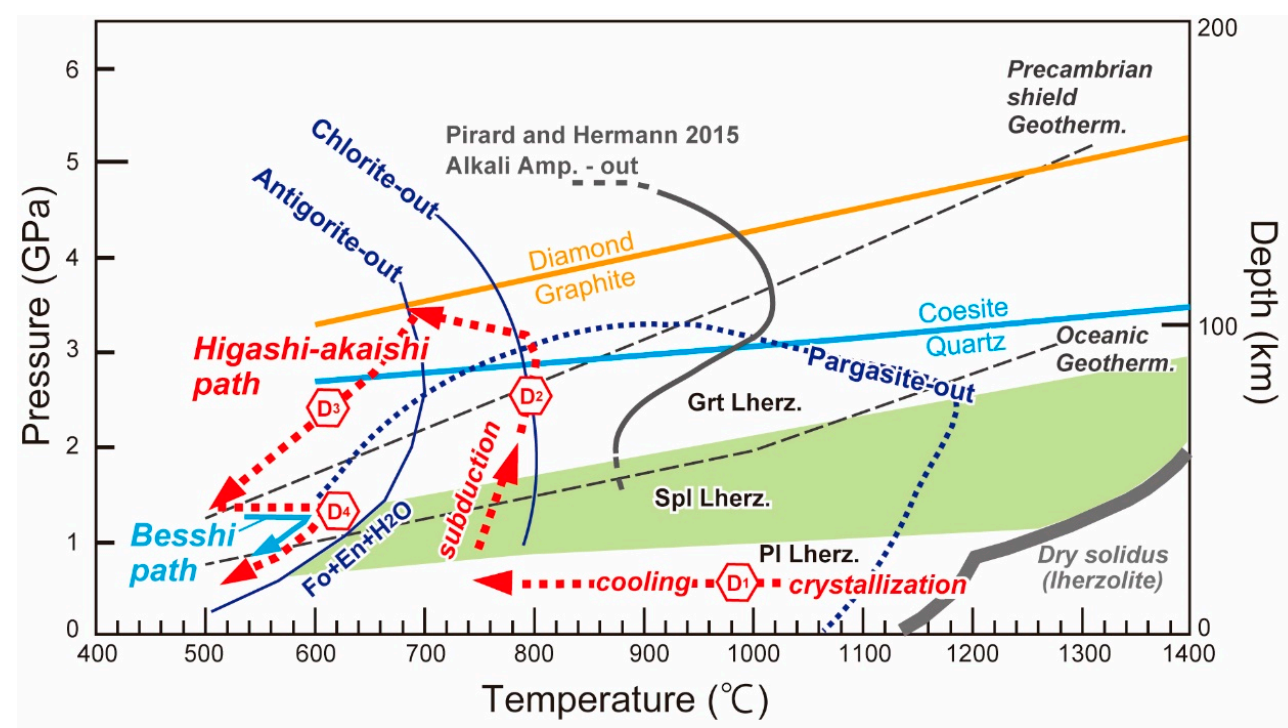

Figure 10. P-T diagram for the stability fields of minerals and facies transitions of peridotite. The P-T trajectory of the Higashi-akaishi peridotite body is from Mizukami and Wallis [27] and Hattori [28]. Geotherms, diamond-graphite and coesite-quartz transition lines are from Green and Ringwood [43], Naemura et al. [44] and Mirward and Massone [45], respectively. The pargasite stability limit was compiled from Foley [37], Fumagalli and Poli [39], Fumagalli et al. [40], Niida and Green [38], and Frost [41], and the alkali amphibole stability limit is from Pirard and Hermann [42].

The presence of possible primary inclusions of pargasite in spinels (Figure 3g) indicates that the HA chromitites were formed within the stability field of pargasite, i.e., at a relatively low-P condition ( $<3 \mathrm{GPa}$ ) (Figure 10). The inclusion pargasite is significantly different in the mode of occurrence and chemistry from the ehimeite, a Cr-dominant $\mathrm{Ca}$ amphibole, formed by reaction between chromitite and the metamorphic fluid at a retrograde stage of the Sanbagawa metamorphism during the exhumation stage [22]. The pargasitic amphibole in spinel may have been unstable at the peak metamorphic condition that the HA complex has experienced $\left(>3 \mathrm{GPa}, 700-800{ }^{\circ} \mathrm{C}\right.$ to $<3.8 \mathrm{GPa}$, $500-700^{\circ} \mathrm{C}$ ) (Figure 10), based on experimental data so far obtained [37-41]. Recent experimental study of alkali amphiboles under hydrous conditions, however, indicates that some alkali amphiboles are potentially stable under such a P-T condition [42] (Figure 10). In summary, the HA chromitites have probably experienced a UHP condition, within the stability field of coesite but slightly lower than the diamond stability field, although no UHP minerals have ever been found.

Presence of the diopside lamellae in spinel from the HA chromitites (Figures 3 and 4) suggests some long duration of subsolidus cooling and/or decompression of the chromitite [4,9]. The exsolved silicate lamellae in the HA chromitites (Figures 3 and 5) are possibly originated from silicate components in the primary magmatic chromian spinel; natural chromitite spinels equilibrated at low temperatures are very poor in $\mathrm{Si}$ and $\mathrm{Ca}$ [1]. The diopside lamellae are dominant in the central part of coarse spinel grains, which is relatively low in $\mathrm{Fe}^{3+}$ and high in $\mathrm{Al}$ contents, and decrease sharply in abundance to their marginal part in banded chromitites (thin chromitite bands) (Figures 3 and 7). Such distribution of silicate lamellae is possibly due to high mobility of the components, which have been diffused away outside the spinel grains to join the silicate matrix during cooling. This is supported by the similarity with the distribution pattern of diopsidic clinopyroxene exsolution lamellae in cooled mantle orthopyroxene porphyroclasts in peridotites (Figure 7), where the high-T diopsidic component was exsolved as lamellae in the central part and diffused out from the marginal part of the orthopyroxene grain (Figure 7).

The HA chromitites are different in geological and petrographic characteristics from typical podiform chromitites from ophiolites, such as those from the Oman ophiolite [4,30]. Mantle harzburgites, which usually host podiform chromitites with a dunite envelope [1], are completely missing in the HA 
peridotite complex. The thick dunite-wherlite-clinopyroxenite suite hosting chromitites in the HA complex is equivalent to a cumulus mantle $[17,32]$ or a kind of Moho transition zone (MTZ) in the sub-arc mantle [46-49]. We interpret that the dunite-dominant HA complex itself is equivalent to the dunite envelope of podiform chromitites, as discussed by Arai and Abe [48] on sub-arc podiform chromitites beneath the Southwest Japan arc.

\subsection{Comparison with the UHP Chromitites from Tibet and the Polar Urals}

The HA chromitites are similar in petrographic feature to UHP chromitites, except for the absence of the peculiar UHP minerals, from Tibet and the Polar Urals. The Lubusa ophiolite, one of the ophiolites that contain UHP chromitites, on the east-end of the Indus-Yarlung-Zangbo suture zone, Tibet (Figure 11a,b) has been interpreted to have originated at a mid-ocean ridge between the Indian and the Asian continents [50]. This ophiolite was obducted as a slice of the Neo-Tethyan oceanic lithosphere due to collision of the two continents in the Early Paleogene (around $65 \mathrm{Ma}$ ) [51], and experienced later modification at a subduction zone environment before its obduction [50]. The Ray-Iz ophiolite, another example of the UHP chromitite occurrence [7], is located in the Polar Ural region (Figure 11c-e), and was emplaced by collision of the Magnitogosrk arc and the East Europian continent block in the mid-Paleozoic around $400 \mathrm{Ma}$ [52]. Ultramafic and mafic rocks in this region reflect a series of westward-directed thrust stacks in which the oceanic and arc sequences lie on the continental margin of the European plate [53].

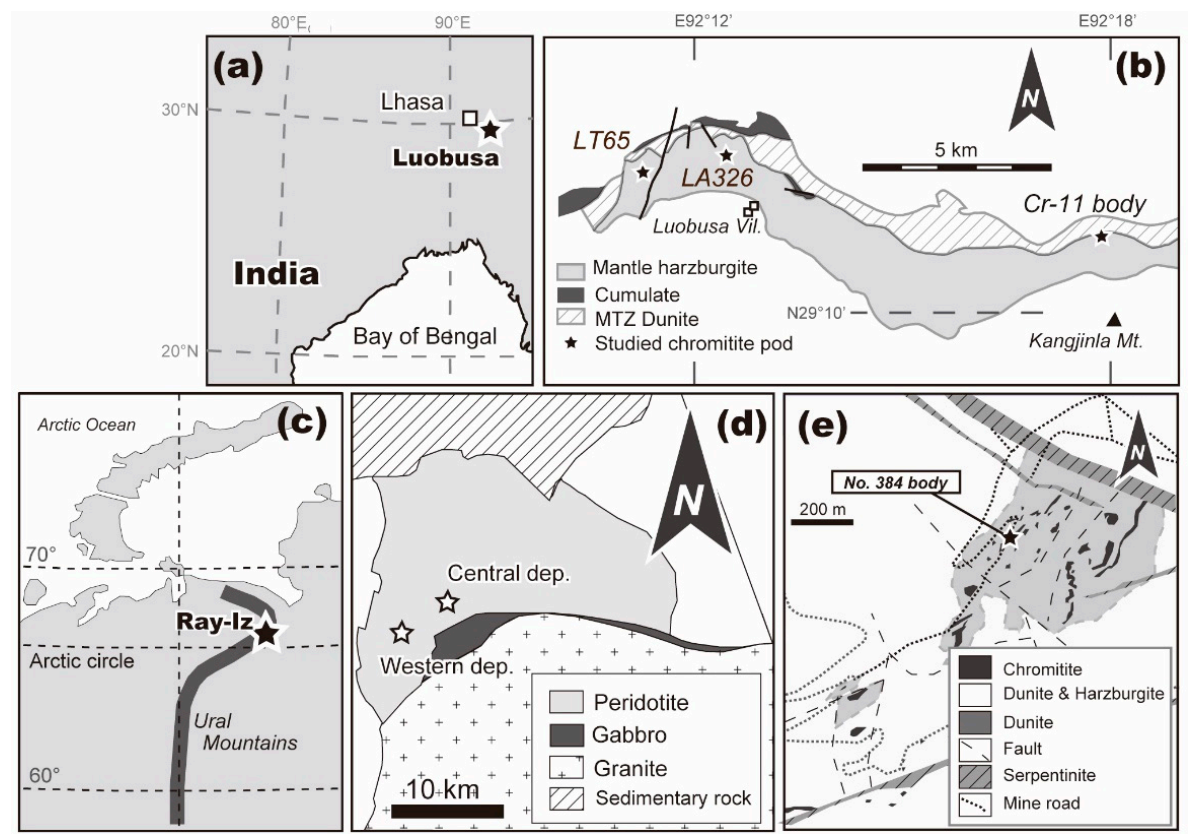

Figure 11. Locality and geological sketch maps of the Luobusa ophiolite, Tibet, and Ray-Iz ophiolite, the Polar Urals. (a) Location of the Luobusa ophiolite. (b) General geological sketch of the Luobusa ophiolite, Tibet. Modified from Zhou et al. [50] and Yamamoto et al. [9]. (c) Location of the Ray-Iz ophiolite. (d) General geological sketch of the Ray-Iz ophiolite, the Polar Urals. Modified from Shmelev [54] and Yang et al. [7]. (e) Geological sketch of the no. 384 chromitite body (diamond-bearing) in the central area of the Ray-Iz massif. Star indicates sampling locality.

As previously mentioned, the spinels from the HA chromitites have numerous diopside lamellae (Figure 3). This feature is shared with the UHP chromitites from Tibet and the Polar Urals $[9,24]$ (Figure 12). Yamamoto et al. [9] and Miura [24] reported silicate lamellae from spinels in the UHP chromitites from Tibet and the Polar Urals, respectively. Such silicate lamellae have been also observed from spinels in UHP metamorphic spinel-garnet peridotites from the Bohemian Massif, Czech Republic [44]. Additionally, pods of the UHP chromitites from both the Tibetan and the Polar 
Ural ophiolites are mostly concordant to the foliation of surrounding mantle peridotite. The structural characteristics of the mantle peridotites suggest that they have experienced deformation possibly via mantle convection flow [55]. Arai et al. [56] observed pull-apart cracks in chromite grains filled by olivine (PACO texture) in the Tibetan UHP chromitites, and suggested the PACO texture possibly indicates brittle deformation of spinels and ductile behavior of olivine at a UHP condition [28]. The PACO texture was also described from the Polar Urals UHP chromitites [24]. As described above, the HA chromitite share the PACO texture (Figure 3b) with the UHP Tibetan and Polar Ural chromitites. This suggests that they share the similar geotectonic history too. In addition, the spinels from both the Tibetan and Polar Ural UHP chromitites show high Cr\#s (around 0.8 to 0.85 ) and low $\mathrm{TiO}_{2}$ contents $(<0.2 \mathrm{wt} \%)$, indicating their arc-related magmatic origin [24,57] (Figure 6). This is consistent with their PGE chemistries, which result favors the highly depleted magma parentage for the UHP chromitites (Figure 9). Again, the UHP chromitites share the similar spinel chemistry and PGE characteristics with the HA chromitites; arc-related depleted magmas formed protoliths of these chromitites. After the igneous formation, the HA chromitites as well as the other UHP chromitites were possibly experienced deep recycling at subduction zones. The deep subduction can produce the UHP chromitites from the sub-arc low-P chromitites (Figure 13). We suggest that the HA chromitite is potentially a UHP chromitite although now UHP minerals such as coesite and diamond have not been found (Figure 10).
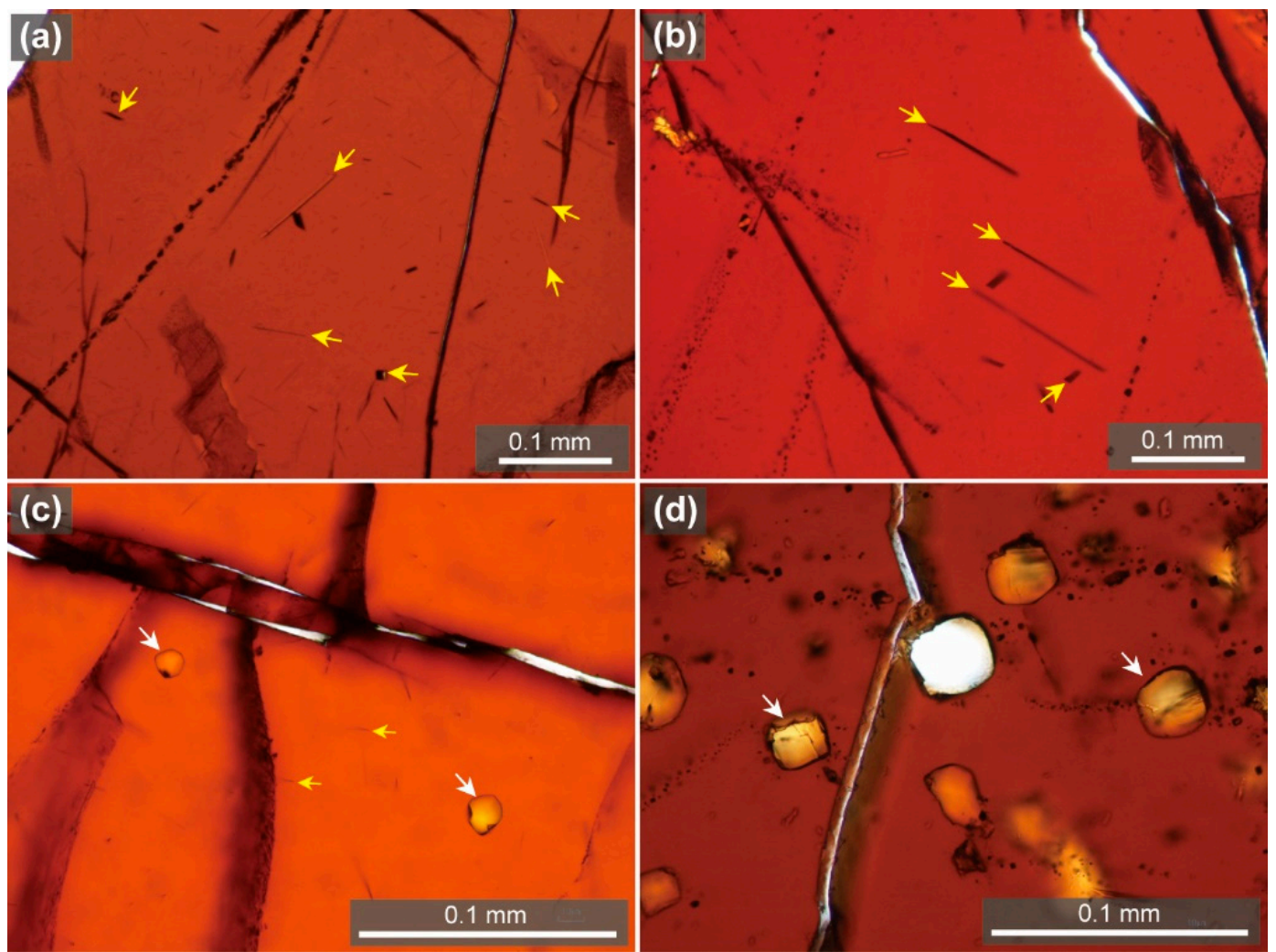

Figure 12. Photomicrographs of micro inclusions in chromian spinel from UHP chromitites from the Luobusa (a,c) and Ray-Iz (b,d) ophiolites. (a) Spinel of the chromitite (Cr-11 body) in the eastern part of the Luobusa ophiolite. Yellow arrows indicate silicate lamellae. (b) Spinel of the chromitite (no. 384 body) in the central area of the Ray-Iz ophiolite. Yellow arrows indicate silicate lamellae. (c) Spinel of the coesite and amphibole bearing chromitite (LA326) in the central part of the Luobusa ophiolite. White arrows indicate amphibole inclusions. (d) Orbicular diopside inclusions (white arrows) in spinel in a diamond-bearing UHP chromitite (no. 384). Note that amphiboles are totally absent in primary inclusions. 
(a)

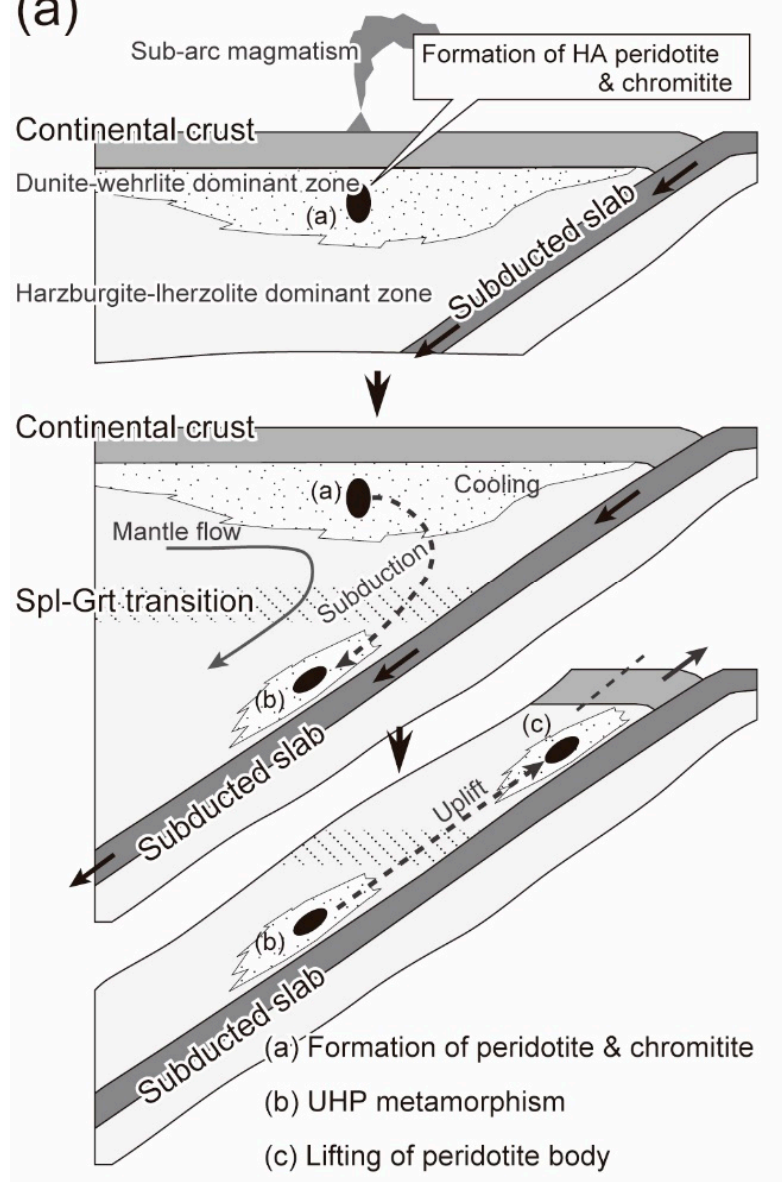

(b) primary hydrous

mineral inclusion

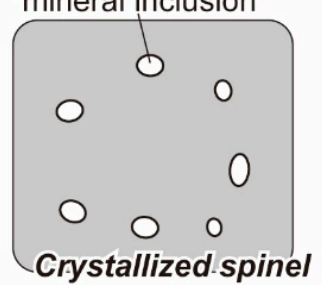

cooling $\downarrow$

diopside lamella

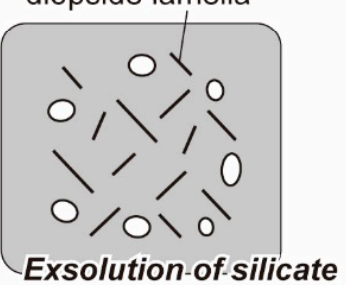

Figure 13. Catoons for genesis of the Higashi-akaishi chromitite and inclusion in chromian spinel. (a) A petrologic model for the HA peridotite body containing chromitite. The igneous formation of the protolith of HA peridotite body at Stage (a). The proto-HA peridotite body was dragged down via the subduction channel by active mantle flow in a supra-subduction zone, and experienced UHP metamorphism (Stage (b)). After the prograde metamorphism, the body experienced retrograde metamorphism due to its uplift (Stage (c)). (b) An illustration showing the evolution of primary silicate inclusions and diopside exsolution lamellae in chromian spinel during subsolidus cooling.

\section{Implications for Origin of UHP Chromitites}

The HA chromitites were formed in a thick MTZ composed of a dunite-wehrlite-clinopyroxenite suite by sub-arc magma, which had a highly depleted feature (Figure 13a) as in a sub-arc lithosphere model based on xenoliths by Arai et al. [58]. After the igneous and subsequent in situ cooling stage, they were transported via subduction channel by active mantle flow within a mantle wedge (a path from (a) to (b) in Figure 12a). Then, the long duration of subsolidus cooling by subducted slab probably induced the exsolution of diopside lamellae in chromian spinel (Figure 13b). The chromitites were deformed under UHP conditions (up to $3.8 \mathrm{GPa}$ ) during the prograde metamorphism of the HA complex, and then the PACO texture was produced in spinel grains (Figure 3b). After the modification at UHP conditions, they were exhumed together with the surrounding Sanbagawa metamorphic rocks (Figures 10 and 13).

Several models for the formation of UHP chromitites were proposed. Ruskov et al. [10] and Yang et al. [7] interpreted these UHP chromitites as deep-mantle igneous products to explain the presence of some UHP minerals, such as euhedral diamonds and possible coesite pseudomorphs after stishovite. They cannot explain, however, geological and petrological features of the UHP chromitites, which are shared with low-P chromitites. Arai $[11,12]$ instead proposed a deep recycling model, where 
the UHP chromitites can be formed from low-P chromitites by UHP metamorphism (deep recycling) via mantle convection flow. This model explains many features of UHP chromitites.

UHP chromitites from both the Tibetan and Polar Ural ophiolites are divided into two types in terms of mineral species as inclusions in spinel [24]. One (e.g., LA326 and LT69 in Figure 10b) is characterized by the coexistence of diopside (and rarely coesite described by Yamamoto et al. [9]) lamellae and primary $\mathrm{Na}$ amphibole inclusion in spinel [24] (Figure 11a,c). The other contains diamonds (e.g., Cr-11 body in Figure 10b and No. 384 body in Figure 10e) [7,8], and is free of the primary $\mathrm{Na}$ amphibole inclusion (Figure 9b,d) [24]. Coexistence of coesite and Na amphibole inclusions in spinel in the former indicates a conditions of relatively low temperature (around 700 to $800^{\circ} \mathrm{C}$ ) and high pressure (around $3 \mathrm{GPa}$ ) (Figure 9), which is possibly available from the mantle wedge. UHP metamorphism in a subduction zone environment is clearly more favorable than the deep-mantle igneous origin beneath mid-ocean ridge $[8,10,59]$ for this type of UHP chromitite (Figure 9). This is concordant with a model of Arai [11,12] where deep recycling to the base of the upper mantle ( $<12-16$ GPa [60-63]) produces UHP chromitites from low-P igneous ones. Current high-P experimental studies in the systems of $\mathrm{MgCr}_{2} \mathrm{O}_{4}-\mathrm{FeCr}_{2} \mathrm{O}_{4}$ and $\mathrm{MgCr}_{2} \mathrm{O}_{4}-\mathrm{Mg}_{2} \mathrm{SiO}_{4}$ suggested that UHP chromitites were possibly formed at shallower parts of mantle than the mantle transition zone [60-63]. Some petrographic and isotopic characteristics of UHP chromitites and surrounding peridotites from Tibet support the UHP metamorphism model in a subduction zone above $[64,65]$. The latter diamond-bearing UHP chromitites are possibly of deeper mantle origin than the former amphibole-bearing UHP chromitites because of the absence of primary amphibole inclusion in spinel (Figure 9). The HA chromitites are similar to the amphibole-bearing type of UHP chromitites in petrographic and chemical characteristics. The UHP chromitites, at least in part, can be formed by UHP metamorphism from low-P chromitites.

Author Contributions: M.M., S.A., T.M., V.R.S., and S.I. collected samples; M.M. prepared samples and performed the Raman spectroscopic and EPMA analyses; M.M., and S.A. wrote manuscript; M.M. designed the figures and tables.

Funding: This study was partly supported by JSPS KAKENHI (grant number 25.8426) and Fukada Grant-in-Aid.

Acknowledgments: We are grateful to E. Pushkarev, D. Kuznetsov, and D. Dyuryagina for their assistance during our fieldwork in the Polar Urals, and to S. Ishigami for his assistance in fieldworks in the Higashi-akaishi peridotite body. S. Yamamoto kindly provided us UHP chromitite samples from Tibet. We appreciate S. Umino, T. Morishita, A. Tamura, and Y. Soda for their discussions. Comments from three anonymous reviewers improved our manuscript.

Conflicts of Interest: The authors declare no conflict of interest.

\section{References}

1. Arai, S.; Yurimoto, H. Podiform chromitites of the Tari-Misaka ultramafic complex, southwestern Japan, as mantle-melt interaction products. Econ. Geol. 1994, 89, 1279-1288. [CrossRef]

2. Zhou, M.; Robinson, P.Y.; Bai, W.J. Formation of podiform chromitites by melt/rock interaction in the upper mantle. Miner. Deposita 1994, 29, 98-101. [CrossRef]

3. Borisova, A.Y.; Ceuleneer, G.; Kamenetsky, V.S.; Arai, S.; Béjina, F.; Abily, B.; Bindeman, I.N.; Polve, M.; Parseval, P.D.; Aigouy, T.; et al. A new view on the petrogenesis of the Oman ophiolite chromitites from microanalyses of chromite-hosted inclusions. J. Petrol. 2012, 53, 2411-2440. [CrossRef]

4. Miura, M.; Arai, S.; Ahmed, A.H.; Mizukami, T.; Okuno, M.; Yamamoto, S. Podiform chromitite classification revisited: A comparison of discordant and concordant chromitite pods from Wadi Hilti, northern Oman ophiolite. J. Asian Earth Sci. 2012, 59, 52-61. [CrossRef]

5. $\quad$ Robison, P.T.; Bai, W.-J.; Malpas, J.; Yang, J.-S.; Zhou, M.F.; Fang, Q.-S.; Hu, X.-F.; Cameron, S.; Staudigei, H. Ultra-high pressure minerals in the Luobusa Ophiolite, Tibet, and their tectonic implications. In Aspects of the Tectonic Evolution of China; Malpas, J., Fletcher, C.J.N., Ali, J.R., Aitchison, J.C., Eds.; Geological Society of London: London, UK, 2004; pp. 247-271.

6. Yang, J.; Dobzhinetskaya, L.; Bai, W.-J.; Fang, Q.-S.; Robinson, P.T.; Zhang, J.; GreenII, H.W. Diamond- and coesite-bearing chromitites from the Luobusa ophiolite, Tibet. Geology 2007, 35, 875-878. [CrossRef] 
7. Yang, J.; Meng, F.; Xu, X.; Robinson, P.T.; Dilek, Y.; Makeyev, A.B.; Wirth, R.; Wiedenbeck, M.; Griffin, W.L.; Cliff, J. Diamonds, native elements and metal alloys from chromitites of the Ray-Iz ophiolite of the Polar Urals. Gondwana Res. 2015, 27, 459-485. [CrossRef]

8. Xu, X.; Yang, J.; Songyong, C.; Qingsong, F.; Wenji, B. Unusual Mantle Mineral Group from Chromitite Orebody Cr-11 in Luobusa Ophiolite of Yarlung-Zangbo Suture Zone, Tibet. J. Earth Sci. 2009, 20, $284-302$. [CrossRef]

9. Yamamoto, S.; Komiya, T.; Hirose, K.; Maruyama, S. Coesite and clinopyroxene exsolution lamellae in chromitites: In-situ ultrahigh-pressure evidence from podiform chromitites in the Luobusa ophiolite, southern Tibet. Lithos 2009, 109, 314-322. [CrossRef]

10. Ruskov, T.; Spirov, I.; Georgieve, M.; Yamamoto, S.; Green, H.W.; McCammon, C.A.; Dobrzhinetskaya, L.F. Mössbauer spectroscopy studies of the valence state of iron in chromite from the Luobusa massif of Tibet: Implications for a highly reduced deep mantle. J. Metamorph. Geol. 2010, 28, 551-560. [CrossRef]

11. Arai, S. Possible recycled origin for ultrahigh-pressure chromitites in ophiolites. J. Miner. Petrol. Sci. 2010, 105, 280-285. [CrossRef]

12. Arai, S. Conversion of low-pressure chromitites to ultrahigh-pressure chromitites by deep recycling: A good inference. Earth Planet Sci. Lett. 2013, 379, 81-87. [CrossRef]

13. Banno, S.; Yoshino, G. Eclogite-bearing peridotite mass at Higashi-akaishi-yama in the Bessi Area, central Shikoku, Japan. In Upper Mantle Symposium New Dehli; Smith, C.H., Sorgenfrei, T., Eds.; Det Berlingske Bogtrykkeri: Copenhagen, Germany, 1964; pp. 150-160.

14. Enami, M.; Mizukami, T.; Yokoyama, K. Metamorphic evolution of garnet-bearing ultramafic rocks from the Gongen area, Sanbagawa belt, Japan. J. Metamorph. Geol. 2004, 22, 1-15. [CrossRef]

15. Enami, M.; Mizukami, T. P-T-D Evolution of the Higashi-akaishi Ultramafic Mass in the Sanbagawa Metamorphic Belt, Central Shikoku, Japan: Subduction of Wedge Mantle Peridotite. J. Geogr. 2004, 113, 617-632. [CrossRef]

16. Mizukami, T.; Wallis, S.; Yamamoto, J. Natural examples of olivine lattice preferred orientation patterns with a flow-normal a-axis maximum. Nature 2004, 427, 432-436. [CrossRef] [PubMed]

17. Hattori, K.; Wallis, S.; Enami, M.; Mizukami, T. Subduction of mantle wedge peridotites: Evidence from the Higashi-akaishi ultramafic body in the Sanbagawa metamorphic belt. Isl. ARC 2010, 19, 192-207. [CrossRef]

18. Wallis, S.R.; Okudaira, T. Paired metamorphic belts of SW Japan: The geology of the Sanbagawa and Ryoke metamorphic belts and the Median Tectonic Line. In The Geology of Japan; Moreno, T., Wallis, S., Kojima, T., Gibbons, W., Eds.; The Geological Society of London: London, UK, 2016; pp. 101-124.

19. Kunugiza, K.; Takasu, A.; Banno, S. The origin and metamorphic history of the ultramafic and metagabbro bodies in the Sanbagawa metamorphic belt. Geol. Soc. Am. Mem. 1986, 164, 375-386.

20. Utsunomiya, A.; Jahn, B.-M.; Okamoto, K.; Ota, T.; Shinjoe, H. Intra-oceanic island arc origin for Iratsu eclogites of the Sanbagawa belt, central Shikoku, southwest Japan. Chem. Geol. 2011, 280, 97-114. [CrossRef]

21. Yamada, M. On the dunite and chromite deposites of the Akaishi mine, Ehime Prefecture. Bull. Geol. Surv. Jpn. 1953, 4, 751-756.

22. Nishio-Hamane, D.; Ohnishi, M.; Minakawa, T.; Yamaura, J.; Saito, S.; Kadota, R. Ehimeite, $\mathrm{NaCa}_{2} \mathrm{Mg}_{4} \mathrm{CrSi}_{6} \mathrm{Al}_{2} \mathrm{O}_{22}(\mathrm{OH})_{2}$ : The first Cr-dominant amphibole from the Akaishi Mine, Higashi-Akaishi Mountain, Ehime Prefecture, Japan. J. Miner. Petrol. Sci. 2012, 107, 1-7. [CrossRef]

23. Arai, S.; Okamura, H.; Kadoshima, K.; Tanaka, C.; Suzuki, K.; Ishimaru, S. Chemical characteristics of chromian spinel in plutonic rocks: Implications for deep magma processes and discrimination of tectonic setting. Isl. ARC 2011, 20, 125-137. [CrossRef]

24. Miura, M. Integrated Petrogenesis of Podiform Chromitites. Ph.D. Thesis, Kanazawa University, Kanazawa, Japan, 2015.

25. Huang, E.; Chen, C.H.; Huang, T.; Lin, E.H.; Xu, J.-A. Raman spectroscopic characteristics of Mg-Fe-Ca pyroxenes. Am. Mineral. 2000, 85, 473-479. [CrossRef]

26. Kunugiza, K. Two contrasting types of zoned chromite of the Mt. Higashi-akaishi peridotite body of the Sanbagawa metamorphic belt, Central Shikoku. J. Jpn. Assoc. Mineral. 1981, 76, 331-342. [CrossRef]

27. Arai, S.; Shimizu, Y.; Ismail, S.A.; Ahmed, A.H. Low-T formation of high-Cr spinel with apparently primary chemical characteristics within podiform chromitite from Rayat, northeastern Iraq. Miner. Mag. 2006, 70, 499-508. [CrossRef] 
28. Arai, S.; Miura, M. Formation and modification of chromities in the mantle. Lithos 2016, 264, $277-295$. [CrossRef]

29. Takahashi, E.; Uto, K.; Schilling, J.-G. Primary Magma Compositions and Mg/Fe Ratios of Their Mantle Residues along Mid Atlantic Ridge $29^{\circ} \mathrm{N}$ to $73^{\circ} \mathrm{N}$; Technical Reports ISEI; Okayama University: Okayama, Japan, 1987; pp. 1-4.

30. Ahmed, A.H.; Arai, S. Unexpectedly high-PGE chromitite from the deeper mantle section of the northern Oman ophiolite and its tectonic implications. Contrib. Miner. Petrol. 2002, 143, 263-278. [CrossRef]

31. Mizukami, T.; Wallis, S.R. Structural and Petrological constraints on the tectonic evolution of the garnet-lherzolite facies Higashi-akaishi peridotite body, Sanbagawa belt, SW Japan. Tectonics 2005. [CrossRef]

32. Hattori, T. Petrology of Higashi-Akaishi Ultramafic Complex in the Sanbagawa Metamorphic Belt, Japan: Cumulates from Magma Related to Highly Depleted Mantle. Master's Thesis, Kanazawa University, Kanazawa, Japan, 2012.

33. Kushiro, I.; Yoder, H.S. Formation of eclogite from garnet peridotite: Liquidus relations in the portion of the system $\mathrm{MgSiO}_{3}-\mathrm{CaSiO}_{3}-\mathrm{Al}_{2} \mathrm{O}_{3}$ at high pressure. In Carnegie Institute Year Book; The John D. Lucas Printing Company: Baltimore, Maryland, USA, 1974; Volume 73, pp. 266-269.

34. Jung, H.; Karato, S. Water-induced fabric transitions in olivine. Science 2001, 293, 1460-1463. [CrossRef] [PubMed]

35. Arai, S. Dunite-harzburgite-chromitite complexes as refractory residue in the Sangun-Yamaguchi zone, western Japan. J. Petrol. 1980, 21, 141-165. [CrossRef]

36. Tzamos, E.; Filippidis, A.; Rassios, A.; Grieco, G.; Michailidis, K.; Koroneos, A.; Stamoulis, K.; Pedrotti, M.; Gamaletsos, P.N. Major and minor element geochemistry of chromite from the Xerolivado-Skoumtsa mine, Southern Vourinos: Implications for chrome ore exploration. J. Geochem. Explor. 2016, 165, 81-93. [CrossRef]

37. Foley, S. High-pressure stability of the fluor- and hydroxyl-endmembers of pargasite and K-richterite. Geochim. Cosmochim. Acta 1991, 55, 2689-2694. [CrossRef]

38. Niida, K.; Green, D.H. Stability and chemical composition of pargasitic amphibole in MORB pyrolite under upper mantle conditions. Contrib. Miner. Petrol. 1999, 135, 18-40. [CrossRef]

39. Fumagalli, P.; Poli, S. Experimentally determined phase relations in hydrous peridotites to $6.5 \mathrm{GPa}$ and their consequences on the dynamics of subduction zones. J. Petrol. 2005, 46, 555-578. [CrossRef]

40. Fumagalli, P.; Zanchetta, S.; Poli, S. Alkali in phlogopite and amphibole and their effects on phase relations in metasomatized peridotites: A high-pressure study. Contrib. Miner. Petrol. 2009, 158, 723-737. [CrossRef]

41. Frost, D.J. The stability of Hydrous Mantle Phases. Rev. Miner. Geochem. 2006, 62, 243-271. [CrossRef]

42. Pirard, C.; Hermann, J. Experimentally determined stability of alkali amphibole in metasomatised dunite at sub-arc pressures. Contrib. Miner. Petrol. 2015. [CrossRef]

43. Green, D.H.; Ringwood, A.E. The stability fields of aluminous pyroxene peridotite and garnet peridotite and their relevance in upper mantle structute. Earth Planet Sci. Lett. 1967, 3, 151-160. [CrossRef]

44. Naemura, K.; Ikuta, D.; Kagi, H.; Odake, S.; Ueda, T.; Ohi, S.; Kobayashi, T.; Svojtka, M.; Hirajima, T. Diamond and other possible ultra-deep evidence discovered in the orogentic spinel-garnet peridotite from the Moldanubian Zone of the Bohemian Massif, Czech Republic. In Ultrahigh-Pressure Metamorphism, 25 Years after the Discovery of Coesite and Diamond; Dobrzhinetskayam, L., Faryad, S.W., Wallis, S., Cuthbert, S., Eds.; Elsevier: Amsterdam, The Netherlands, 2011; pp. 77-105.

45. Mirwald, P.W.; Massonne, H.-J. The Low-High Quartz and Quartz-Coesite Transition to 40 kbar Between $600{ }^{\circ} \mathrm{C}$ and $1600{ }^{\circ} \mathrm{C}$ and Some Reconnaissance Data on the Effect of $\mathrm{NaAlO}_{2}$ Component on the Low Quartz-Coesite Transition. J. Geophys. Res. 1980, 85, 6983-6990. [CrossRef]

46. Arai, S.; Abe, N. Podiform chromitite in the arc mantle: Chromitite xenoliths from the Takashima alkali basalt, Southwest Japan arc. Miner. Deposita 1994, 29, 434-438. [CrossRef]

47. Parlak, O.; Delaloye, M.; Bíngöl, E. Mineral chemistry of ultramafic and mafic cumulates as an indicator of the arc-related origin of the Mersín ophiolite (southern Turkey). Geol. Rundsch. 1996, 85, 647-661. [CrossRef]

48. Arai, S.; Abe, N.; Hirai, H.; Shimizu, Y. Geological, petrographical and petrological characteristics of ultramafic-mafic xenoliths in Kurose and Takashima, northern Kyushu, southwestern Japan. Sci. Rep. Kanazawa Univ. 2001, 46, 9-37.

49. Miura, M.; Arai, S. Platinum-group element and mineral characteristics of sub-arc chromitite xenoliths from the Takashima alkali basalt, southwest Japan arc. Can. Miner. 2014, 52, 899-916. [CrossRef] 
50. Zhou, M.-F.; Robinson, P.T. Malpas, J.; Li, Z. Podiform chromitites in the Luobusa ophiolite (Southern Tibet): Implications for melt-rock interaction and chromite segregation in the upper mantle. J. Petrol. 1996, 37, 3-21. [CrossRef]

51. Aitchison, J.C.; Badengzhu, D.A.M. Remnants of a Cretaceous intra-oceanic subduction system within the Yarlung-Zangbo suture (southern Tibet). Earth Planet Sci. Lett. 2000, 183, 231-244. [CrossRef]

52. Shmelev, V.R.; Meng, F.C. Thenature and age of basic rocks of the Rai-Iz ophiolite massif (Polar Urals). Dokl. Earth Sci. 2013, 451, 758-761. [CrossRef]

53. Savelieva, G.N.; Nesbitt, R.W. A synthesis of the stratigraphic and tectonic setting of the Uralian ophiolites. J. Geol. Soc. 1996, 153, 525-537. [CrossRef]

54. Shmelev, V.R. Mantle ultrabasites of ophiolite complexes in the Polar Urals: Petrogenesis and geodynamic environments. Petrology 2011, 19, 618-640. [CrossRef]

55. Cassard, D.; Nicolas, A.; Rabinovitch, M.; Moutte, J.; Leblanc, M.; Prinzhofer, A. Structural classification of chromite pods in southern New Caledonia. Econ. Geol. 1981, 76, 805-831. [CrossRef]

56. Arai, S.; Miura, M.; Yamamoto, S.; Shmelev, V. Textural and petrological characteristics of ultrahigh-pressure chromitites, indicating a mantle recycling origin? In Proceedings of the EGU General Assembly, Vienna, Austria, 7-12 April 2013.

57. Xu, X.; Yang, J.; Ba, D.; Guo, G.; Robinson, P.T.; Li, J. Petrogenesis of the Kangjinla peridotite in the Luobusa ophiolite, Southern Tibet. J. Asian Earth Sci. 2011, 42, 553-568. [CrossRef]

58. Arai, S.; Hirai, H.; Uto, K. Mantle peridotite xenoliths from the Southwest Japan arc: A model for the sub-arc upper mantle structure and composition of the Western Pacific rim. J. Miner. Petrol. Sci. 2000, 95, 9-23. [CrossRef]

59. Xiong, F.; Yang, J.; Robinson, P.T.; Xu, X.; Liu, Z.; Li, Y.; Li, J.; Chen, S. Origin of podiform chromitite, a new model based on the Luobusa ophiolite, Tibet. Gondwana Res. 2015, 27, 525-542. [CrossRef]

60. Ishii, T.; Kojitani, H.; Tsukamoto, S.; Fujino, K.; Mori, D.; Inaguma, Y.; Tsujino, N.; Yoshino, T.; Yamazaki, D.; Higo, Y.; et al. High-pressure phase transitions in $\mathrm{FeCr}_{2} \mathrm{O}_{4}$ and structure analysis of new post-spinel $\mathrm{FeCr}_{2} \mathrm{O}_{4}$ and $\mathrm{Fe}_{2} \mathrm{Cr}_{2} \mathrm{O}_{5}$ phases with meteoritical and petrological implications. Am. Miner. 2014, 99, 1788-1797. [CrossRef]

61. Ishii, T.; Kojitani, H.; Fujino, K.; Yusa, H.; Mori, D.; Inaguma, Y.; Matsushita, Y.; Yamaura, K.; Akaogi, M. High-pressure high-temperature transitions in $\mathrm{MgCr}_{2} \mathrm{O}_{4}$ and crystal structures of new $\mathrm{Mg}_{2} \mathrm{Cr}_{2} \mathrm{O}_{5}$ and post-spinel $\mathrm{MgCr}_{2} \mathrm{O}_{4}$ phases with implications for ultrahigh-pressure chromitites in ophiolites. Am. Miner. 2015, 100, 59-65. [CrossRef]

62. Ishii, T.; Tsujino, N.; Arii, H.; Fujino, K.; Miyajima, N.; Kojitani, H.; Kunimoto, T.; Akaogi, M. A shallow origin of so-called ultrahigh-pressure chromitites, based on single-crystal X-ray structure analysis of the high-pressure $\mathrm{Mg}_{2} \mathrm{Cr}_{2} \mathrm{O}_{5}$ phase, with modified ludwigite-type structure. Am. Miner. 2017, 102, 2113-2118. [CrossRef]

63. Akaogi, M.; Kawahara, A.; Hiroshi, K.; Yoshida, K.; Anegawa, Y.; Ishii, T. High-pressure phase transitions in $\mathrm{MgCr}_{2} \mathrm{O}_{4} \cdot \mathrm{Mg}_{2} \mathrm{SiO}_{4}$ composition: Reactions between olivine and chromite with implications for ultrahigh-pressure chromitites. Am. Miner. 2018, 103, 161-170. [CrossRef]

64. Huang, M.-X.; Yang, J.-J.; Powell, R.; Mo, X. High-pressure metamorphism of serpentinized chromitite at Luobusa (Southern Tibet). Am. J. Sci. 2014, 314, 400-433. [CrossRef]

65. McGowan, N.M.; Griffin, W.L.; González-Jiménez, J.M.; Belousova, E.; Afonso, J.G.; Shi, R.; McCammon, C.A.; Pearson, N.J.; O’Reilly, S.Y. Tibetan chromitites: Excavating the slab graveyard. Geology 2015, 43, 179-182. [CrossRef]

(C) 2018 by the authors. Licensee MDPI, Basel, Switzerland. This article is an open access article distributed under the terms and conditions of the Creative Commons Attribution (CC BY) license (http://creativecommons.org/licenses/by/4.0/). 